\title{
管理型廃棄物海面処分場の維持管理の実態に 関する全国踏査および遮水性能の評価
}

\author{
足立 一美 \\ 正会員 太陽工業株式会社（干154-0001＼cjkstart東京都世田谷区池尻2-33-16） \\ E-mail : ak003460@mb.taiyokogyo.co.jp
}

\begin{abstract}
2007年に港湾法が改正され, 廃棄物埋立護岸が港湾施設とされるとともに, 性能規定化がなされ, 保有 水などが漏出しないよう建設し, 維持管理すべきこととされた。 そこで, 本研究では全国の主なサイトへ 赴き維持管理の実態について現地踏査を行った. 踏査における注目点は, 処分場の全般的状況, 護岸構造, 管理水位，構造物の変状・劣化状況などである。現地踏査の結果にもとづき維持管理中に遮水工が損傷し た場合を想定して, 境界条件である管理水位および海洋の特徴である海洋の特徵である潮位変動を考慮し, Eulerian-Lagrangian FEMを活用することによって, 保有水が遮水工から長期間にわたって漏出した場合の 周辺海域への影響について解析を行った。
\end{abstract}

Key Words : Waste Reclamation Site, Nationwide Survey, Maintenance, Seawall, Sea Environment

\section{1. はじめに}

2007年に港湾法が改正され，廃棄物埋立護岸が同 法第2条第5項に定める港湾施設に指定され，また同 法第56条の2の2第1項において定める港湾の施設の 技術上の基準に係る省令に適合することが求められ るようになった。具体的には，施設が保有すべき性 能についての規定化が図られ，併せて施設の変状や 劣化による性能の低下を事前に防止するような予防 的な維持管理が規定された。このような背景から，

「港湾の施設の技術上の基準・同解説」 ${ }^{1)}$ が発刊さ れ，これにもとづいて実務における運用がなされて いる。 また, 廃棄物埋立護岸については，2008年に 具体的な技術マニュアル ${ }^{2)}$ が発刊され広く利用さ れている.しかしながら, 廃棄物埋立護岸の維持管理 については，処分場内に廃棄物と污染水が貯留され るという独自の特性に応じた技術の一層の開発が望 まれる。

\section{2. 研究の目的}

本研究では, 処分場の全国踏査によって維持管理 の実態を把握し，実際の維持管理に当たって最も重 視すべき遮水性能を評価するための手法を開発する ことによって，より適正な維持管理に資することを 目的とする.

\section{3. 管理型廃棄物海面処分場の現地踏査}

海面処分場の維持管理の実態を把握するために, 全国の主なサイト 10 箇所一赴き現地踏査を行った. 踏査における注目点は, 処分場の全般的状況, 護岸 構造, 管理水位, 構造物の変状・劣化などである.

\section{（1） 全般的状況}

処分場の規模は 100ha 程度から 5ha 程度までで, 立地特性に応じた維持管理がなされている.しかし, 污染水の処理 - 漏出防止, 護岸 - 遮水工の定期点検, 周辺海域の水質監視などの海面処分場のシステムと しての共通点も多いことが分かった。

\section{(2) 護岸構造}

処分場の護岸構造は，重力式ケーソン護岸，鋼矢 板護岸または捨石護岸である. 遮水工には主として, 水深が大きく大規模な処分場では，遮水矢板が用い られ、通常の規模の処分場では，経済性に優れる遮 水シートが用いられている。

\section{（3）管理水位}

写真-1 に，水位の管理および浸出水の処理のため の揚水ポンプの一例を示した。管理水位は，外海水 位の平均水位に近い值に設定されている例が多く, 埋立地から海側への動水勾配が小さく，外海への浸 透はほとんど生じない。但し，多量の降雨があれば 管理水位は一時的に上昇することがあり，筆者が行 った現地踏査においては $105 \mathrm{~cm} の$ 上昇が生じた例が 確認できた。また逆に，降水のない日が永く続いた 場合には $15 \mathrm{~cm}$ の水位低下が生じた例を確認できた。

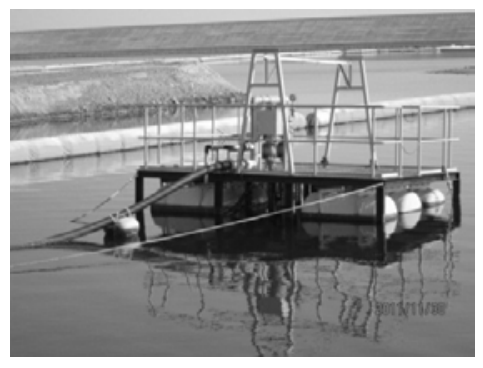

写真- 1 揚水ポンプの例 


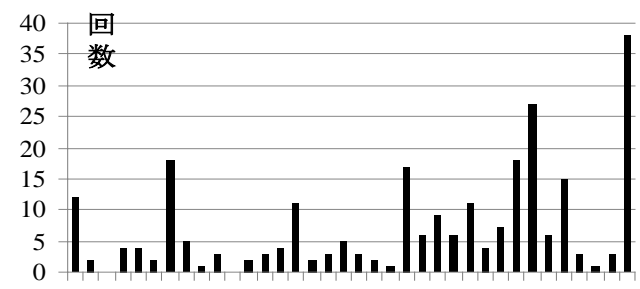

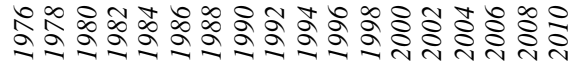

図-1 日降雨量 $400 \mathrm{~mm}$ 以上の年間発生回数

図-1に示寸ように，近年，集中豪雨に見舞われる ことが多くなってきており，注意が必要である ${ }^{3)}$. 越波による内水位上昇については, 護岸水吒き上の 越波痕跡（ $\mathrm{NaCl}$ の凝固）を確認できたが, 特に問題 となった事例はなかった。

\section{（4）構造物の変状 · 劣化状況}

表-1 に示寸ように，護岸・遮水工について月に 1 回の頻度で目視による点検が行われており, 護岸・ 遮水工に大きな変状や劣化は見られなかった。

しかしながら，遮水矢板を用いた例では海水によ る軽微な腐食が始まった例があり，今後，注視して いくことが求められる. またこれとは別に, 中心気 圧 $930 \mathrm{hPa}$, 最大瞬間風速 $61 \mathrm{~m} / \mathrm{s}$ を記録した台風 1217 号の来襲時に，処分場の外側からの波力および潮汐 力 (潮位偏差 $80 \mathrm{~cm}$ ) によって遮水シートが変形した ことが確認できた。しかしながら，遮水シートは $300 \%$ 以上の伸び変形に耐えられることから, その損 傷に至っていないと考えられる。異常気象時には海 洋からの漂着ごみが護岸に付着することがあり，そ の除去と併せ海上の船舶から護岸の点検を行ってい る例があった.なお, 海中部の点検が必要とされるよ うな異常な変状を生じた例は, 確認できなかった。 一般の港湾構造物では, 1 年に 1 2 回の頻度での定

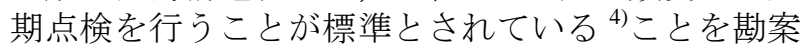
すれば, 廃棄物埋立護岸においてはより綿密な定期 点検が行われていると言える.

\section{（5）水質監視の実態}

表-2に処分場内の浸出水の水質と，処理水質の例 を示す. 浸出水は処理した後, 海域一放流される. 浸出水の処理は，常に行わなければならないから， 処分場内水質は日常的に調べられている.

表-3に処分場周辺海域の水質監視の例を示寸.

海域の水質基準は, 生活環境項目と健康項目につ いて定められており，表のとおり月1回以上，年4回 以上および年2回以上の頻度でのそれぞれの監視が なされている。健康項目は, 1971年にカドミウム, シアンなど8項目の告示がなされて以来, 過去, 順次 追加されてきており現在では20余の項目となってお $り^{5)}$ ，厳格な基準值による規制がなされている。

表-1 護岸・遮水工の定期点検の例

\begin{tabular}{|c|c|c|}
\hline 点検籄所 & 護 & 遮 \\
\hline 点検項目 - 内容 & $\begin{array}{c}\text { 護岸天端高の異常, } \\
\text { クラッ・陷没 }\end{array}$ & $\begin{array}{c}\text { 遮水シートの破れ，め } \\
<れ \cdot \text { 異常 }\end{array}$ \\
\hline 4月2日 & 0 & 0 \\
\hline 5月 1日 & 0 & 0 \\
\hline 6月1日 & 0 & 0 \\
\hline 7月2日 & 0 & 0 \\
\hline 8月1日 & 0 & 0 \\
\hline 9月3日 & 0 & 0 \\
\hline
\end{tabular}

表-2 浸出水質と処理水質の例

\begin{tabular}{c|c|c|c}
\hline & 単 位 & 浸出水質 & 処理水質 \\
\hline $\mathrm{PH}$ & & $5 \sim 10$ & $6 \sim 8$ \\
\hline $\mathrm{COD}$ & $\mathrm{mg} / \mathrm{L}$ & 160 & 8 \\
\hline $\mathrm{SS}$ & $\mathrm{mg} / \mathrm{L}$ & 40 & 10 \\
\hline $\mathrm{T}-\mathrm{N}$ & $\mathrm{mg} / \mathrm{L}$ & 40 & 1 \\
\hline $\mathrm{T}-\mathrm{P}$ & $\mathrm{mg} / \mathrm{L}$ & 1.5 & 0.09 \\
\hline
\end{tabular}

表-3 処分場周辺の水質監視の例

\begin{tabular}{|c|c|c|c|c|c|}
\hline 項 目 & 測 定 対 象 & $\begin{array}{l}\text { 基準値(基準省令に } \\
\text { よる) }\end{array}$ & 備 考 & 頻 度 & 場 所 \\
\hline 一般項目 & $\begin{aligned} \text { 水温，透明度, } \\
\text { 不揮性性游物質 }\end{aligned}$ & & & 月1回以上 & \multirow{29}{*}{$\begin{array}{l}\text { 基本監 } \\
\text { 視点及 } \\
\text { U゙補助 } \\
\text { 監視点 }\end{array}$} \\
\hline \multirow{5}{*}{$\begin{array}{l}\text { 生活環 } \\
\text { 境項目 }\end{array}$} & 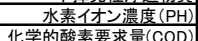 & $\begin{array}{r}7.0-8.3 \\
8 \mathrm{mo}(12 \mathrm{~F}\end{array}$ & \multirow{6}{*}{$\begin{array}{l}\text { 基準値は, } \\
\text { 海域の類型 } \\
\text { によって異 } \\
\text { なる. } \\
\text { なる. }\end{array}$} & \multirow{4}{*}{ 月1回以上 } & \\
\hline & 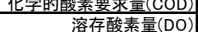 & $\frac{8 \mathrm{mg} / \text { L } \mathrm{Y}}{2 \mathrm{mg} \text { (L以上 }}$ & & & \\
\hline & 大腸菌群数 & $1.000 \mathrm{MPN} / 100 \mathrm{~mL}$ 以下 & & & \\
\hline & $\begin{array}{r}n \text {-ヘキサン抽出物質 (油 } \\
\text { 分等) }\end{array}$ & 検出されないこと & & & \\
\hline & 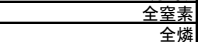 & $\begin{aligned} 1 \mathrm{mg} / \text { L以下 } \\
0.09 \mathrm{mg} / \text { L以下 }\end{aligned}$ & & 年4回以上 & \\
\hline \multirow{23}{*}{$\begin{array}{l}\text { 健 康 } \\
\text { 項 目 }\end{array}$} & が゙ミ全焙 & & & \multirow{23}{*}{ 年2回以上 } & \\
\hline & 氒ミウム & $0.01 \mathrm{mg} /$ L以下 & \multirow{22}{*}{$\begin{array}{l}\text { すべて } \\
\text { 基準値 } \\
\text { 未満 }\end{array}$} & & \\
\hline & 全シアン & 検出されないこと & & & \\
\hline & 六価クロム & $\frac{0.01 \mathrm{mg} / \text { L以下 }}{0.05 \mathrm{mg} / \text { T }}$ & & & \\
\hline & 素 & $0.01 \mathrm{mg} /$ L以下 & & & \\
\hline & 総水銀 & $0.0005 \mathrm{mg} /$ L以下 & & & \\
\hline & アルキル水銀 & 検出されないこと & & & \\
\hline & PCB & 検出されないこと & & & \\
\hline & ジクロロメタン| & $0.02 \mathrm{mg} /$ L以下 & & & \\
\hline & 四塩化炭素 & $0.002 \mathrm{mg} / \mathrm{LWT}$ & & & \\
\hline & 1,2-ジクロロエタン & $0.004 \mathrm{mg} / \mathrm{LWT}$ & & & \\
\hline & 1.1-ジクロロエチレン & $0.02 \mathrm{mg} / \mathrm{LWT}$ & & & \\
\hline & シスー1,2-ジクロロエチレン & $0.04 \mathrm{mg} /$ L以下 & & & \\
\hline & 1.1,1-トリクロロエタン & $0.01 \mathrm{mg} / \mathrm{LWT}$ & & & \\
\hline & 1,1,2-トリクロロエタン & $0.0006 \mathrm{mg}$ /L以下 & & & \\
\hline & トリクロロエチレン & $1 \mathrm{mg} / \mathrm{L}$ 以下 & & & \\
\hline & テトラクロロエチレン & $0.01 \mathrm{mg} /$ L以下 & & & \\
\hline & 1,3-ジクロロプロペン & $0.002 \mathrm{mg} /$ L以下 & & & \\
\hline & チウラム & $0.006 \mathrm{mg} /$ L以下 & & & \\
\hline & シマジン & $0.003 \mathrm{mg} / \mathrm{LW下}$ & & & \\
\hline & チオベンカルフ & $0.02 \mathrm{mg} / \mathrm{LWT}$ & & & \\
\hline & ベンゼン & $0.01 \mathrm{mg} /$ L以下 & & & \\
\hline & & & & & \\
\hline
\end{tabular}

\section{4. 浸透・移流分散解析による遮水性能の評価 ${ }^{6), 7), 8)}$}

\section{(1) 支配方程式}

密度流を考慮した飽和・不飽和浸透流方程式は， 式(1)のとおりである。

$$
\begin{aligned}
& \rho_{f} \theta \gamma \frac{\partial c}{\partial t}+\rho\left\{\beta S_{s}+C_{s}(\theta)\right\} \frac{\partial \psi}{\partial t}= \\
& \frac{\partial}{\partial x_{i}}\left\{\rho k_{i j}^{s} k_{r}(\theta) \frac{\partial \psi}{\partial x_{j}}+\rho k_{i 3}^{s} k_{r}(\theta) \rho_{r}\right\}
\end{aligned}
$$

ここに,

$\phi$ :圧力水頭, $\theta$ : 体積含水率, $S s$ : 比貯留係数, $C S(\theta)$ : 比水分容量, $k_{i j}{ }^{5}$ ： 飽和透水係数, $k_{r}(\theta)$ : 比透水 係数, $c$ : 濃度, $t$ : 時間, $\rho_{f}$ : 溶媒の密度, $\rho$ : 流 体の密度, $\rho_{r}$ ： 溶媒の密度に対する流体の密度比

$\left(\rho / \rho_{f}\right), \beta=1$ : 飽和領域, 0 : 不飽和領域, $\gamma$ : 溶 質の密度比.

移流分散方程式は，式(2)のとおりであり，右辺第 1 項が分散項，第 2 項が移流項である.

$R \theta \rho \frac{\partial c}{\partial t}=\frac{\partial}{\partial x_{i}}\left(\theta \rho D_{i j} \frac{\partial c}{\partial x_{j}}\right)-\theta \rho v_{i} \frac{\partial c}{\partial x_{i}}-R \theta \rho \lambda c-Q_{c}$

ここに,

$R$ : 遅延係数, $D_{i j}$ : 分散係数, $v_{i}$ : 間隙内流速, $\lambda$ : 減衰係数, $Q_{c}$ : 源泉項.

\section{(2) 分散係数}

分散係数は，式(3)のとおりである ${ }^{9)}$.

$$
D_{i j}=\alpha_{T}|| V|| \delta_{i j}+\left(\alpha_{L}-\alpha_{T}\right) \frac{V_{i} V_{j}}{\|V\|}+\alpha_{m} \tau \delta_{i j}
$$

ここに, 
$\alpha_{T}$ : 横分散長, $\alpha_{L}$ : 縦分散長, $V_{i}$ : 実流速ベクトル, $\|V\|$ 実流速ベクトルのノルム, $\alpha_{m}$ : 分子拡散係数, $\tau$ : 屈曲率, $\delta_{i j}$ : クロネッカのデルタ.

本研究で用いたこれらの值は，表-4に示すとおり である. 分散係数を 2 次元場について示すと, 図-2 図-4のとおりであり，浸透流速に対する非線形性を 取り入れている.

多孔質媒体としての地盤内の移流分散現象につい ては，参考文献 10) に的確な解説があるので参照 されたい。

表-4 分散係数のパラメータ

\begin{tabular}{c|c|c}
\hline 項 目 & 単位 & 用いた值 \\
\hline 横分散長 & $\mathrm{m}$ & 0.3 \\
\hline 縦分散長 & $\mathrm{m}$ & 3 \\
\hline 分子拡散係数 & $\mathrm{m}^{2} / \mathrm{s}$ & $1.0 \times 10^{-9}$ \\
\hline 屈曲率 & & 0.5 \\
\hline
\end{tabular}

$D_{x z}$

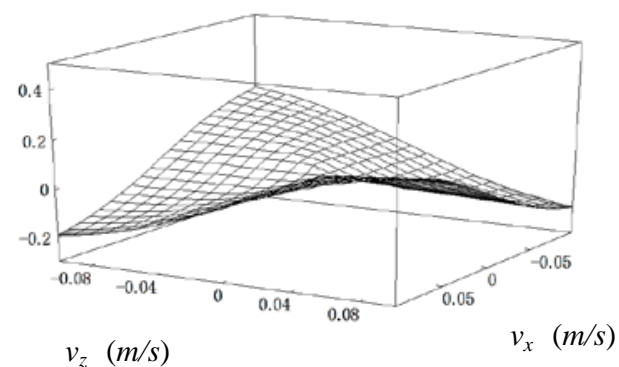

図-2 分散係数 $\left(D_{x z}=D_{z x}\right)$

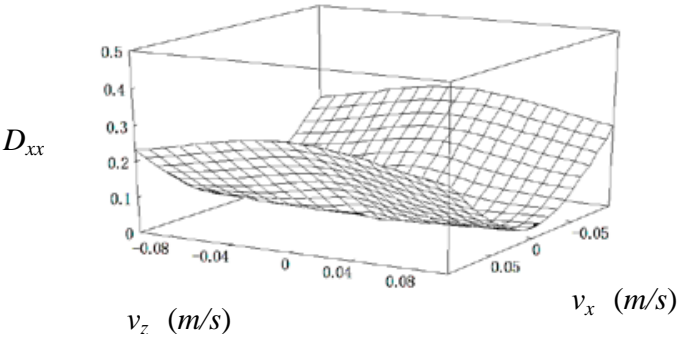

図-3 分散係数 $\left(D_{x x}\right)$

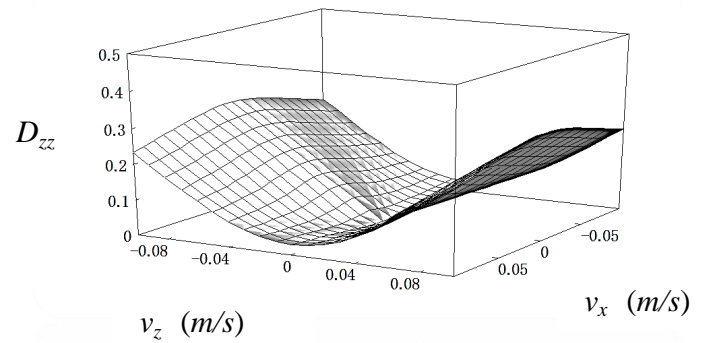

図-4 分散係数 $\left(D_{z z}\right)$

\section{（3）移流分散方程式の離散化}

濃度 $c$ は, 移流による濃度 $c_{a}$ と分散による $c_{d}$ の和 で表されるものとする.

$$
c(x, z, t)=c_{a}(x, z, t)+c_{d}(x, z, t)
$$

式(4)を式(2)に代入すれば,式(2)は移流方程式と分 散方程式に分けられる。移流方程式を解くために, 式(5)の “Lagrange 微分”を用いて，運動している流 体とともに移動する Lagrange 座標系に変換する.

浸透流方程式と分散方程式は, Euler 座標系で, 移 流方程式は Lagrange 座標系で離散化し, これによっ て高精度な浸透・移流分散現象の計算を可能にする.

$$
\frac{D}{D t}=\frac{\partial}{\partial t}+v_{i} \frac{\partial}{\partial x_{i}}
$$

\section{5. 遮水シートを用いた場合の遮水性能の評価}

\section{（1）遮水工の損傷割合}

現地踏査では遮水工が損傷した例は，確認されな かった。

そこで本研究では既往の研究 ${ }^{11), 12)}$ に倣い，損傷が 小さい場合には 2.5 個/ha とし, 損傷が大きい場合に は 200 個/ha とした。損傷箇所の直径は，ともに $d=$ $1.0 \mathrm{~cm}$ とした.

\section{（2）等価な透水係数の求め方}

既往の研究 ${ }^{11), 12)}$ によれば損傷部を有する遮水シー トが下層部と完全に密着している場合，シートの損 傷部を通過する流量は，式(6)によって与えられる.

$$
Q=2.62 k_{u} d h_{w}
$$

ここに

$k_{u}$ : シート下部層の透水係数, $d$ : 損傷部の直径, $h_{w}$ : シートと下部層間の水頭差.

シートの単位断面積当たりの損傷の割合を $f$ と すれば，単位断面積当たりの流量，すなわちフラッ クス $q$ は，式(7)により与えられる.

$$
q=2.62 f k_{u} d h_{w}
$$

式(7)は， 2 次元軸対称モデルについて求められた ものである.本研究では以上の既往の研究成果を活 用し，これを図-5 の左上に示した図に対して適用す る。図-5 の左上の図を右上の図のように，これと等 価な透水係数 $k_{e q}$ をもつ厚さ $t_{g}$ のシート亡, 透水係数 $k_{u}$, 厚さ $t_{u}$ の下部層からなる 1 次元流れで置き換え ることを考える。このとき，シートと下部層を通過 するフラックス $q_{e q}$ は式(8)により与えられる.

$$
q_{e q}=\frac{t_{u}+t_{g}}{\frac{t_{u}}{k_{u}}+\frac{t_{g}}{k_{e q}}} \frac{h_{w}}{t_{u}+t_{g}}=\bar{k} \bar{l}
$$

ここに， $\bar{k}$ と $\bar{l}$ は，それぞれ遮水シートと下部層 の平均透水係数および平均動水勾配である.

$q=q_{\mathrm{eq}}$ とおくと, 損傷した遮水シートの等価換算透 水係数 $k_{e q}$ は，式(9)によって与えられる. 


$$
k_{e q}=\frac{t_{g}}{\frac{h_{w}}{q}-\frac{t_{u}}{k_{u}}}=\frac{t_{g}}{\frac{1}{2.62 f k_{u} d}-\frac{t_{u}}{k_{u}}}
$$

遮水シートの厚さは $0.3 \mathrm{~cm}$ であり，これをそのま まの厚さでモデル化しようとすると, 数值解析上の 安定性と解の精度を確保するために，シートおよび その近傍のメッシュ・サイズを非常に小さくしなけ ればならない。 そうすると, 節点数が増大し計算時 間が著しく増大するため，実用的な時間内に計算を 終えることができない。

そこで，モデル全体の節点数を減らすため，図-6 に示すように FEM 要素の遮水シートの厚さを大き くして透水係数 $k_{e q}$ の遮水シートを上部層側に延長 して，要素の長さに等しいだけの厚さを $t_{v}$ とし，そ の平均透水係数を式(10)によって与えた.

$$
k_{e q}^{\prime}=\frac{t_{v}}{\frac{t_{v}-t_{g}}{k_{v}}+\frac{t_{g}}{k_{e q}}}=\frac{t_{v}}{\frac{t_{v}-t_{g}}{k_{v}}+\frac{1}{2.62 f k_{u} d}-\frac{t_{u}}{k_{u}}}
$$

このような取扱いによって, 遮水シート近傍の流 線は実際と異なることになるが，漏出量は，変わら ない.

(3) 透水係数および入力定数

上記の方法によって求めた透水係数を表-5に示す.
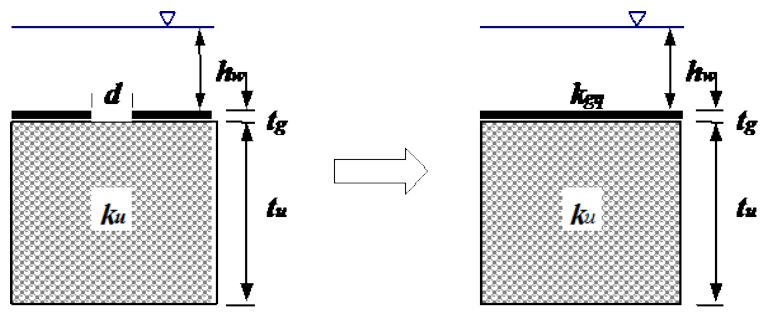

図-5＼cjkstart等価換算係数への換算の概念
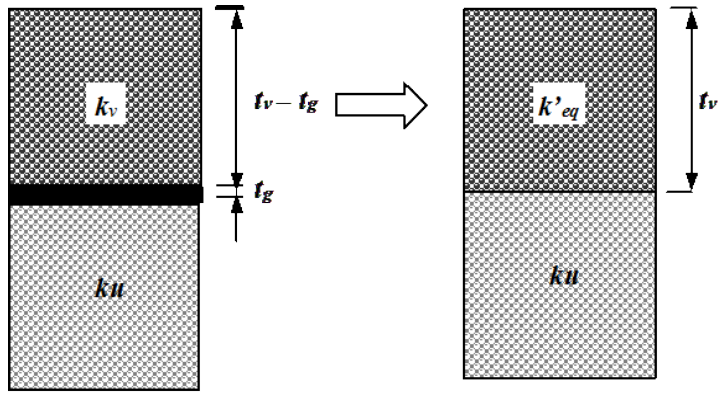

図-6 FEM 解析の際の透水係数の与え方

表 -5 透水係数

\begin{tabular}{r|c|c|c}
\hline & 単 位 & 損傷小の場合 & 損傷大の場合 \\
\hline 遮水シートの厚さ & $\mathrm{cm}$ & 0.3 & 0.3 \\
\hline $\begin{array}{r}\text { 損傷箇所の直径 } \\
\text { 遮水シートの等価換算 } \\
\text { 透水係数 }\end{array}$ & $\mathrm{cm} / \mathrm{s}$ & $1.31 \times 10^{-9}$ & $1.05 \times 10^{-7}$ \\
\hline 上部層の透水係数 & $\mathrm{cm} / \mathrm{s}$ & $1.00 \times 10^{-3}$ & $1.00 \times 10^{-3}$ \\
\hline
\end{tabular}

\begin{tabular}{|c|c|c|c|}
\hline 項 & 目 & 単 位 & 用いた值 \\
\hline \multirow{2}{*}{ 透水係数 } & 海底地盤 & $\mathrm{m} / \mathrm{s}$ & $1.0 \times 10^{-5}$ \\
\hline & 鉛直地盤 & $\mathrm{m} / \mathrm{s}$ & $1.0 \times 10^{-7}$ \\
\hline \multicolumn{2}{|c|}{ 有効間隙率 } & & 0.4 \\
\hline \multicolumn{2}{|c|}{ 比貯留係数 } & $\mathrm{m}^{-1}$ & $2.0 \times 10^{-5}$ \\
\hline \multicolumn{2}{|c|}{ 遅延係数 } & & 1 \\
\hline
\end{tabular}

表-6 入力定数

透水係数のほかの本研究におけるFEMによる浸 透・移流分散解析に際して用いた入力定数を，表-6 に示す.

\section{（4）境界条件}

浸透流方程式(1)および移流分散方程式(2)を解く 際の境界条件は，次のとおりである。

\section{a) 外海水位 :}

・潮位変動がない場合：+1.0m で一定.

・潮位変動がある場合: 平均水位 $+1.0 \mathrm{~m}$, 振幅 $1.0 \mathrm{~m}$, 周期 12 時間の正弦波形(L.W.L.: 0.0m, H.W.L.: 2.0m).

b) 管理水位 : $+1.5 \mathrm{~m}$ で一定.

c) 污染水の濃度 : $1\left(C / C_{0}\right)$ で一定.

大潮の際には，外海水位が大きく変動し動水勾配 が大きなることによって，浸透流速，分散係数およ び移流も大きくなる。したがって潮位は，その平均 をとるのではなく正弦波形によって H.W.L. と L.W.L. を近似した。また，上記の境界条件においては，外 海水位を意図的に高く設定していることから，前述 の集中豪雨による管理水位の上昇なども考慮されて いる.

\section{(5) 計算結果}

\section{a) 漏出濃度のプロファイル}

図-7 に外海水位を一定とした場合（潮位変動がな い場合）の計算結果を示す。明らかに，污染水の外 海への漏出が生じている。この場合は定常状態の解 析であり，計算時間間隔は 2 日（48 時間）で数值安 定性が得られた。図-8 に外海水位に潮位変動がある 場合の計算結果を示す．污染水は捨石マウンドから 外海へ漏出しておらず，外海水位を一定とした場合 に比較して漏出量は抑制されている。この非定常状 態の解析では，計算時間間隔は 1 時間である.

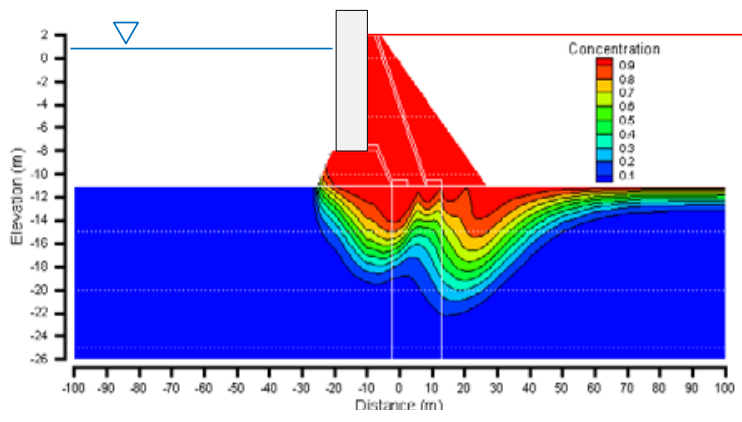

図-7 潮位変動がない場合（50 年後） 


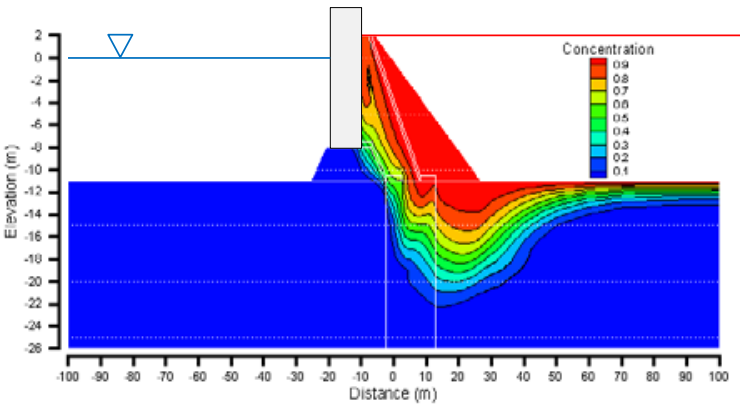

図-8＼cjkstart潮位変動がある場合（50 年後）

\section{b) 漏出量のフラックス}

周辺海域の污染の原因となる遮水工の損傷による 処分場内の污染水の $x=0$ の点での漏出量を, 図-9 のフラックスの形で示し, 実用に供することとした. 但し, 図-9 は $x=0$ の点での漏出量を比較したもの であり潮位変動がある場合には図-8で分かるように まだケーソンの法線の内側に留まっており，海域へ の漏出はしていない.

漏出量のフラックス $\mathrm{S}$ は，式(11)で計算される.

$$
S=\Sigma\left(c_{i} v_{i} \Delta H_{i}\right)
$$

ここで, $C_{i}$ : 濃度の比 $\left(\mathrm{C} / C_{0}\right), \quad v_{i}$ : 実流速, $\Delta H_{i}$ ：有限要素ひとつの長さで， $\Sigma$ は鉛直方向への 和を意味している.

これに, 処分場内の污染水の濃度 $C_{0}(\mathrm{mg} / \mathrm{L})$ およ び漏出時間を乗ずれば，単位奥行当たりの污染物質 の質量が得られる.

\section{(6) 潮位変動による漏出抑制のメカニズム}

計算の結果, 潮位変動を考慮した場合には污染水 の漏出が抑制されることが分かったので，図-10の 長さ $100 \mathrm{~cm}$ の一次元の移流分散モデルによる解析に よって, そのメカニズムを解明した。 すなわち, 図 -11の右側から拡がった濃度(1) 海側（左側）か らの潮位上昇による処分場方向への浸透流によって 戻され，濃度分布は(2)になり漏出は抑制される。ま た，図-11の(3)，処分場からの新たな濃度の供給 がない場合である。このことから，現象の非線形性 によって初期状態に戻らないことが分かった。

図-8の計算は, (2)の状態に相当している.

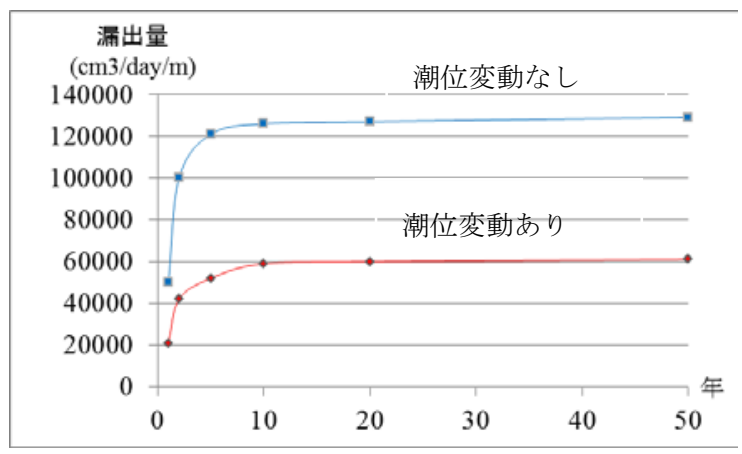

図-9＼cjkstart漏出量のフラックス

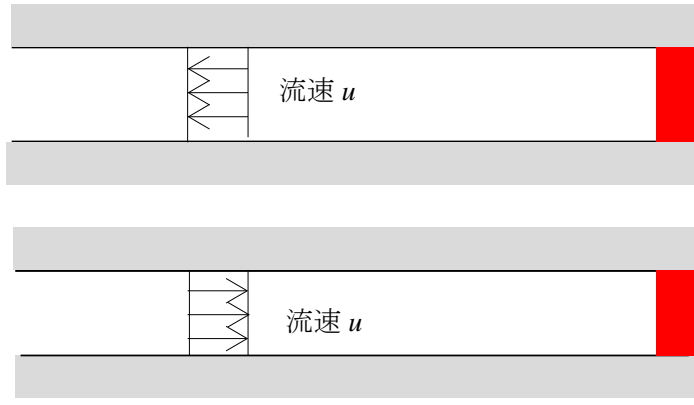

図-10 一次元の移流分散解析

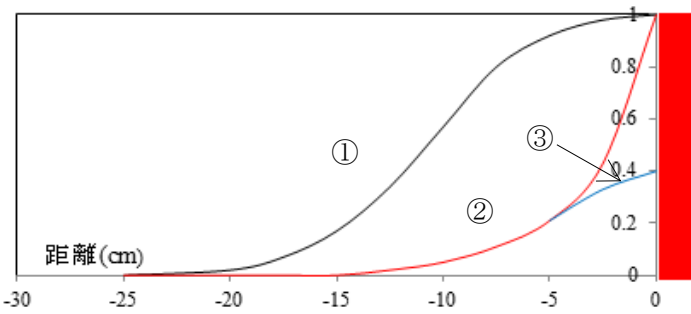

図-11＼cjkstart污染濃度の拡がりと戻り

\section{2 重遮水矢板護岸の遮水性能の評価}

\section{(1) 解析断面および入力定数}

前章においては遮水シートを用いた解析結果を示 したが，本章では遮水矢板を用いた場合の解析結果 を示す，図-12に，現地踏查結果を参考にして設定 した計算の対象とした 2 重遮水矢板護岸の断面を示 寸．また，表-7に入力定数を示す.

\section{(2) 計算結果}

4 章において示した支配方程式にもとづいて行な った 2 重遮水矢板護岸に対する浸透・移流分散現象 の計算結果を図-13 に示す。紙幅の制約から，ここ では潮位変動がある場合のみを示した。

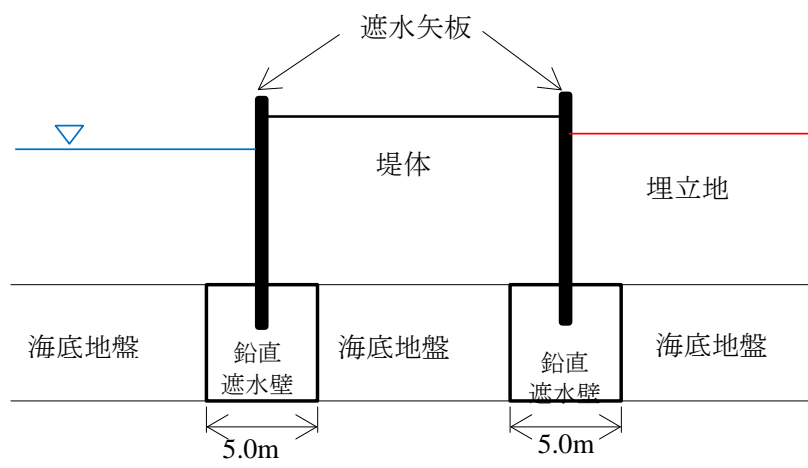

図-12 2 重遮水矢板護岸の断面

表-7 入力定数

\begin{tabular}{c|c|c|c}
\hline & 単位 & 損傷小 & 損傷大 \\
\hline 矢板漏出部の透水係数 & $\mathrm{cm} / \mathrm{s}$ & $2.73 \times 10^{-6}$ & $3.16 \times 10^{-5}$ \\
\hline 堤体の透水係数 & $\mathrm{cm} / \mathrm{s}$ & $1.00 \times 10^{-3}$ & $1.00 \times 10^{-3}$ \\
\hline 矢板の等価換算透水係数 & $\mathrm{cm} / \mathrm{s}$ & $1.00 \times 10^{-7}$ & $1.00 \times 10^{-6}$ \\
\hline
\end{tabular}




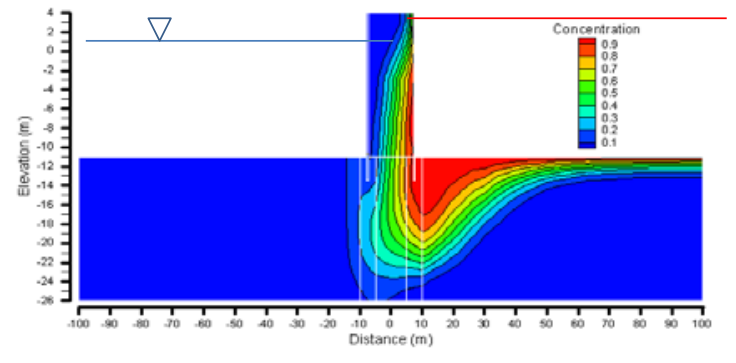

図-13＼cjkstart潮位変動がある場合（50 年後）

遮水矢板を用いた場合についても，遮水シートを 用いた場合と同様にして，等価換算透水係数を求め た。 その際に既往文献 ${ }^{13)}$ にもとづき, 継ぎ手部に遮 水材を塗布した鋼矢板の透水係数は $10^{-8} \mathrm{~cm} / \mathrm{s}$ 以下と 評価できるので，損傷のない鋼矢板も同じように設 定した. このように矢板の損傷および潮位変動を考 慮して 50 年間の長期の遮水性能の評価ができた.な お，計算には「Dtransu-2D/EL」を用いた。

\section{7. 結論}

海面処分場の埋立護岸においては, 月に1回の頻度 で護岸・遮水工の定期点検が行われるとともに，水 質の監視も攸格に行われるなど全般的に良好な維持 管理が行われていることが明らかになった.ただし， 外海の異常な条件による緊急点検については明記し た事例は非常に少なく，今後，高潮・高波による護 岸・遮水工の変形や，近年頻発する集中豪雨による 管理水位の急激な上昇, 鋼矢板の初期的な腐食など, 留意すべき事項を具体的に明らかにした。

また，浸透・移流分散解析によって遮水工に損傷 を生じた場合の処分場内の污染水の漏出量を, 外海 水位に潮位変動を与えて長期間にわたって計算する 方法を示すとともに，潮位変動による漏出の抑制効 果のメカニズムを解明した。ささらに漏出量をフラッ クスとして示し，実用に供することができた。

外海水位を一定とした場合の計算は，潮位差が小
さい場合の近似と解釈することができ，この場合に は漏出量が大きくなることが分かった.したがって, 潮位差が小さい海域の処分場においても異常時の緊 急点検がより重要となることが分かった.

これらの知見は海面処分場のより適正な維持管理 ならびに, 周辺海域の環境保全に資するものである.

\section{参考文献}

1）（社）日本港湾協会 : 港湾の施設の技術上の基準・同 解説, 2007.

2) (財) 港湾空間高度化環境研究センター: 管理型廃裹 物埋立護岸設計・施工・管理マニュアル (改訂版), 2008.

3) 気象庁 : 気候変動監視レポート2011，2012.

4) (財) 沿岸技術研究センター: 港湾の施設の維持管理 技術マニュアル，p.43， 2007.

5) 中杉修身: 水質環境基準の見直し之埋立処分, 廃棄物 学会誌, Vol.10,No.2,pp.128-137,1999.

6) 西垣 誠, 菱谷智幸, 橋本 学, 河野伊一郎 : 飽和 不飽和領域における物質移動を伴う密度依存地下水流 の数值解析手法に関する研究, 土木学会論文集 No.511/ III-30, pp.135-144, 1995.

7) Neuman, S.P.: A Eulerian- Lagrangian Numerical Scheme for the Dispersion-Convection Equation Using Conjugate Space-Time Grids, Journal of Computational Physics, Vol.41, pp.270-294, 1981.

8) Neuman, S.P.: Adaptive Eulerian- Lagrangian Finite Element Method for Advection-Dispersion, International Journal for Numerical Method in Engineering, Vol.20, pp.321-337, 1984.

9) Bear, J.: Dynamics of Fluids in Porous Media, pp.605-612, American Elsevier, 1972.

10) 嘉門雅史, 大嶺 聖, 勝見 武: 環境地盤工学, pp.20-32, 共立出版, 2010 .

11) 嘉門雅史, 乾 徹, 遠藤和人, 伊藤圭二郎, 勝見 武: 遮水シートの損傷を考慮した廃棄物処分場遮水工の性 能評価, 第 4 回環境地盤工学シンポジウム発表論文集, pp.273-278, 2001.

12) 嘉門雅史, 乾 徹: 管理型廃棄物処分場の地盤工学的 問題と対策，土木学会論文集 No.701/ III -58,pp.1-15,2002.

13）根切り工事と地下水一調查・設計から施工まで一, pp.70-71, 土質工学会, 1991.

\section{NATIONWIDE SURVEY ON STATUS-QUO OF MAINTENANCE OF WASTE RECLAMATION SITES AND CALCULATION OF CUT-OFF PERFORMANCE OF THEIR BARRIERS}

\section{Kazumi ADACHI}

High-quality maintenance of seawalls and cut-off structures by which the contaminated water is stored is strongly required so as to preclude it from leaking into surrounding sea. This paper describes the status-quo of maintenance of waste reclamation sites by means of in-situ survey most all over Japan.

Taking the facts described from the above survey into account, in case of failure of cut-off structures, which are usually made of geo-membrains or steel sheet piles, seepage and advection-dispersion phenomena are analyzed by using Eulerian-Lagrangian finite element method in order to clear the environmental risk on surrounding sea of waste reclamation sites. 